rev.relac.int.estrateg.segur.11(2):137-159,2016

\title{
AN ANALYSIS OF THE CRISIS IN UKRAINE, AND ITS THREE CONFLICTS (21 OF NOVEMBER 2013, THROUGH 23 OF MAY 2014)*
}

\author{
Cristián Faundes**
}

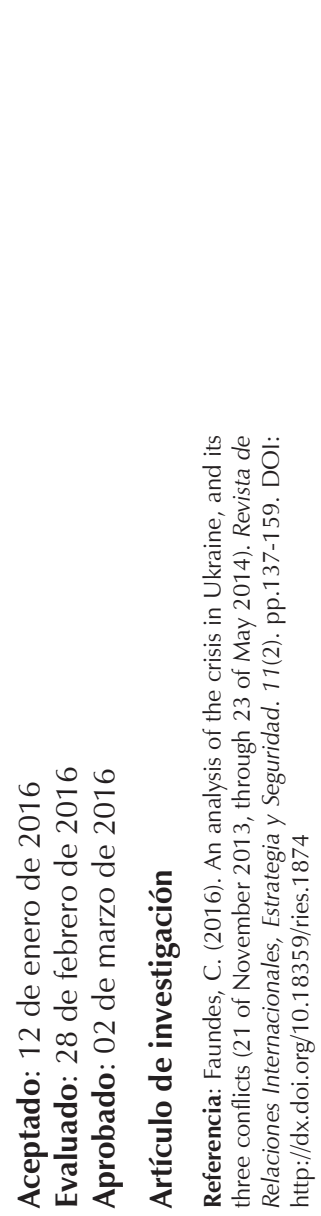

\section{ABSTRACT}

This paper presents the results of a study of the crisis in Ukraine, guided by the following question: which is the intensity of the crisis in Ukraine between November 2013 and May 2014? The information collected for this research involves 293 events evaluated and translated into quantitative data by the author with the objective to elaborate a curve reflecting the intensity of the conflict. Considering that the situation under scrutiny involves several conflicts, one curve of intensity was not enough to follow the course of events, but three were needed to track the

This paper is the result of a research study on the Crisis in Ukraine held at the Center for Strategic Studies of the Chilean Army's War College. Project number: CEEAG-01-2014.

** Investigador académico en temas de seguridad y defensa. Sus líneas de trabajo incluyen la teoría de conflictos y las relaciones entre los países del Cono Sur. Se ha especializado en la problemática de los recursos naturales y el estudio del agua dulce como factor de conflictos. Ha presentado sus investigaciones en congresos internacionales y cátedras de postgrado. Se desempeña como Investigador asociado en la Jefatura de Estudios de la Academia de Guerra del Ejército. Periodista, licenciado en información social. Pontificia Universidad Católica de Chile. Magíster en Ciencias Militar, mención Conflicto y Negociación Internacional, Academia de Guerra del Ejército de Chile. Magíster en Seguridad y Defensa, mención en Política de Defensa. Academia Nacional de Estudios Políticos y Estratégicos. Correo electrónico: cfaundess@acague.cl 
facts that are intertwined by policies in, around and about Kiev, which reveals the particular complexity of the case of study. During the second phase, the internal conflict drags the other two, but the efforts to reduce the intensity of these are not effective to moderate the internal one. The method applied reveals its value as a flexible tool that allows the evaluation of a complex situation in a simple way, but also exposes the fact that none of the divergences is settled.

Keywords: Civil War; International Security; Ukraine.

\section{UN ANÁLISIS DE LA CRISIS EN UCRANIA Y SUS TRES CONFLICTOS (21 DE NOVIEMBRE DE 2013 A 23 DE MAYO DE 2014)}

\section{RESUMEN}

Este artículo presenta los resultados de un estudio a partir de la siguiente pregunta de investigación: ¿cuál es la intensidad de la crisis en Ucrania entre noviembre 2013 y mayo 2014? Se identifican 293 sucesos que son evaluados y traducidos a datos cuantitativos, con el objeto de elaborar una curva que refleje la intensidad del conflicto. Considerando que este caso involucra varias disputas, se ha hecho insuficiente generar una única curva de intensidad para graficar lo acontecido; en cambio, se necesitaron tres para hacer el seguimiento de los hechos, que se encuentran entrelazados por políticas formuladas al interior de Ucrania, algunas en torno al país y finalmente otras respecto del mismo. Ello revela la particular complejidad del caso en estudio. Durante la segunda fase de la crisis, la divergencia interna arrastra las otras dos, pero los esfuerzos por reducir su intensidad no son efectivos para moderar el problema interno. El método aplicado en el estudio destaca como una herramienta flexible que permite realizar la evaluación de una situación compleja en una forma simple, asimismo da cuenta que ninguna de las controversias se ha solucionado.

Palabras clave: Guerra Civil; Seguridad Internacional; Ucrania.

\section{UMA ANALISE DA CRISE DA UCRÂNIA E SEUS TRÊS CONFLITOS (21 DE NOVEMBRO DE 2013 A 23 DE MAIO DE 2014)}

\section{RESUMO}

Este artigo apresenta os resultados de um estudo sobre a crise na Ucrânia, guiada pela pergunta seguinte: qual é a intensidade da crise da Ucrânia entre novembro 
de 2013 e maio 2014? As informações obtidas por esta pesquisa envolvem 293 eventos, avaliados e traduzidos em dados quantitativos pelo autor, com o objetivo de elaborar um gráfico que reflete a intensidade do conflito. Considerando que a situação em apreço envolve vários conflitos, uma cifra de intensidade não foi o suficiente para seguir o curso dos acontecimentos, sendo necessárias mais três para acompanhar os fatos que estão interligados por políticas dentro, ao redor e sobre Kiev, o que revela a especial complexidade do caso em estudo. Durante a segunda fase da crise, o conflito interno arrasta os outros dois, mas os esforços para reduzir a sua intensidade não são eficazes para moderar o problema interno. O método usado no estudo constitui uma ferramenta flexível, que permite a avaliação de uma situação complexa de forma simples, também expõe o fato de que nenhuma das divergências é liquidada.

Palavras-chave: Guerra Civil; Segurança Internacional; Ucrânia.

\section{Introduction}

Authors from Sociology and the discipline of International Relations have been eager to establish a model to measure the intensity of conflicts. One of the key problems relates to the quantification of facts to translate a series of actions into a readable, consistent and logical curve on a graph to visualize the evolution of a conflict. Ministries and Departments of Foreign Affairs need these kind of tools as valuable instruments to diagnose the strategic landscape, whether they represent countries directly involved in a conflict, a State that has legitimate interests in it, or need to monitor the situation in an area of awareness.
Conflicts are inherent to human interactions; they derive from the pursuit of incompatible interests (Martínez de Murguía, 1999: 17-18). If latent conflicts are not transformed promptly, the actors involved may trigger one or multiple crisis, provoking a perception of threat. The complexity to diagnose a crisis is obvious; in this context, the Curve of the Intensity of Conflict is a tool to simplify the process. The crisis in Ukraine is a special example of the difficulty to do a proper follow-up of events, particularly because it is impossible to track the facts concerning this crisis from a unique perspective, from one stand point to build one and only curve.

Some examples, the UCDP/PRIO Conflict Dataset; Heidelberg Institute for International Conflict Research's Conflict Barometer; Conflict Information System (CONIS) database; the Shock of Conflict SHoC Model, among others. 
This paper presents the results of a study of the crisis in Ukraine, with the aim to determine the intensity of the crisis in Ukraine, between November 2013 and May 2014. The information collected for this research involves 293 events that were evaluated and translated into quantitative data. One curve was not enough to follow the course of events; there is the need to draw three of them to track the facts that are intertwined by policies in, around and about Kiev. The method applied admits an orderly disaggregation of data that, in this particular case, enables a deeper understanding of a complex situation that involves several conflicts.

Even though the term Crisis is fairly defined and understood, there is some difficulty determining when a crisis is actually happening. It is also particularly challenging to establish which is the starting point, and the end of it. In this context, it is debatable if after two years, Ukraine is still enduring a crisis or else.

From another perspective, it is pertinent to analyze the case considering its particular characteristics. It is worthy of note the fact that this crisis begun as an internal political phenomena, that after three months attracts international actors. It escalates from the streets of Kiev to the offices of the Kremlin in Moscow, reaches NATO's Central Command in Brussels and even expands its influence to the Oval Office at the White House in
Washington, DC. The developments that take part in the crisis of Ukraine are the most critical in Europe after the end of the Cold War. Not because of the degree of violence, but somehow it evidences the underlying conflict between the West and Russia, up to a point in which the confidence building measures carefully designed to set up a partnership for security between NATO and Russia, suddenly faded away. The crisis in Ukraine marks the moment in which distrust stands between Moscow and Washington provoking the most significant moment of tension since the Cold War. Consequently, a renewed perception of threat activated worries about the use of intercontinental missiles and even nuclear weapons.

\section{Conflict, crisis and the curve of intensity.}

Martínez de Murguía (1999) states that a conflict concerns a relationship between two or more organized groups, within a nation or between States that have incompatible interests; which induces them to confront each other while attempting to achieve their objective. However, Dougherty and Pfaltzgraff (1981) indicate that this kind of interaction implies more than a mere competition; they consider that in a dynamic of conflict, the adversaries seek to improve their own position reducing the one of the opponents.

A conflict is particularly sensitive when it manifests as a crisis, once a key player 
challenges an adversary. In a situation of crisis there is a perception of a threat to a nation, its territories, citizens, military forces, possessions, or vital interests, "that develops rapidly and creates a condition of such diplomatic, economic, or military importance that commitment of military forces and resources is contemplated to achieve national objectives" (Joint Chiefs of Staff, 2010: 55). Then, during a crisis, the dialectic of the conflict accelerates, reducing the timeframe to respond. This means that decision makers need to gain the initiative, keep it, and maintain the liberty of action, meanwhile policy makers are under pressure to produce, in a very short period of time, an array of options for decision makers to asses. A proper diagnose of the situation is critical, particularly because, while willing to take control of the situation, a key player in the conflict would want to avoid raising the temperature... other might be interested on promoting an escalation. The diagnosis includes not only facts per se, but also the possible impacts that decisions, actions and declarations might produce, and finally the perceptions of the public opinion, of the adversary, and allies and partners.

The curve of intensity of conflict is an instrument to measure the evolution of a conflict. According to Michael Lund (2009), it is built upon the understanding that conflicts have a basic life history, they evolve in stages, rises and falls in intensity over time, progressively towards war or peace. The result is a graphic representation of what is happening on terrain, so it helps to visualize the facts in perspective, particularly to understand their dynamic. An acute diagnostic of the situation serves to successfully manage a conflict and even identify key points to resolve it. More in detail, taking note of how sensitive a crisis is, the results derived from a curve of conflict might be even more valuable for decision makers.

To collect an appropriate amount of data to build a graph it is required an extensive review of news stories, reports, interviews and academic papers on the matter. To draw a proper curve it is necessary to examine every single day of the period under scrutiny, identify key events that determine the course of the relationship (or the dynamic) and pointing out coherently and consistently the value of every occurrence. Only then, it is possible to establish the 'tone' or the 'level' of the relationship.

The curve of intensity is more valuable as an instrument when it is used to measure events that are actually happening, for example while a crisis is under development. However, it can also give substantial feedback while analyzing a conflict on perspective. In the case of this research, it has been particularly useful to identify the interdependence of three conflicts that mingle in a crisis. Moreover, particularly, to observe that the study 
of a crisis needs to be disaggregated to understand its complexity, especially according to the conflicts involved.

The curve integrates conceptual and interpretative elements. To translate the data in operational terms, every one of the 293 events identified in the study has been categorized conceptually under the following definitions: Difference, contradiction, polarization, violence, war, ceasefire, agreement, normalization and reconciliation. Once the occurrence is under one of these categories it is valued according to its level of intensity: "low", "medium" or "high".

\section{Definitions}

Difference: At this point of the relationship, there is an identification of initial differences. These are manifested in meetings and through the press, but always in the form of exchange of opinions and points of view. Dialogue and the search for agreements is predominant.

Contradiction: the dialogue among actors is less fluid because the contraposition of interests and values is deep, that is why it is difficult to reach for agreements. There are fewer exchanges of ideas and points of view, fewer meetings and encounters. On a higher level of contradiction, there are official discourses and declarations on the press disqualifying the adversary. There also might be mutual accusations around the impossibility to reach accords. Divergent positions echoes to the civil society.

Polarization: progressively the citizens get involved in the conflict. The antagonism reaches the streets with marches of support to one or the other side, there are signs of discrimination and intolerance. The press cites provoking and disqualifying opinions. On its highest level, the intolerance might be reflected in electoral propaganda with political leaders assuming positions towards a social identification with the conflict. Progressively opportunities for dialogue and the reach of agreements get narrowed.

Violence: when measures of force take part in the conflict, on its higher levels an actor seeks to harm the counterpart. People might take the streets or iconic buildings, there are massive arrests and bloodshed. Events are classified as 'low', 'medium' or 'high' according to the expansion of violence, quantity of people involved in the incidents and amount of cities involved, also with regard to the quality or impact of the incidents concerning who was affected (a relevant person in office or a leader of protesters), and the degree of violence. In terms of military force, exercises and readiness could be considered as low level of violence.

War: when there are direct actions of hostility, which involve the use of firearms or arm systems and operations 
with at least a minimum level of operative and logistic capacity. In an act of war, the weaker adversary has the capacity to respond and react against an aggression, can even cause harm to the stronger part; it can hold its position and counts with enough support to sustain the fight ${ }^{4}$.

Ceasefire: it is the result of a truce, so it is only possible to get to this point after a conflict had reached a level of war. Indicates that the parts have been able to reach a minimum level of convergence allowing the ceasefire.
There could be isolated points of struggle. It has an equivalent level to violence because it is assumed that the motives that triggered the armed conflict are still latent. A successful ceasefire generates proper conditions for dialogue by the reduction of violence and the promotion of trust.

Accord: this point is reached once there is a document signed by the parties involved. It is equivalent to the level of polarization due to the difficulties inherent to the implementation of any accord and especially related to the

Table 1. Concepts, levels and values applied to the events considered for the curve of conflict

\begin{tabular}{|c|c|c|c|c|}
\hline \multicolumn{2}{|c|}{ Increasing intensity } & \multirow[b]{2}{*}{ Value } & \multicolumn{2}{|c|}{ Decreasing intensity } \\
\hline Concept & Level & & Level & Concept \\
\hline \multirow{3}{*}{ War } & High & 75 & High & \multirow{3}{*}{ War } \\
\hline & Middle & 70 & Middle & \\
\hline & Low & 65 & Low & \\
\hline \multirow{3}{*}{ Violence } & High & 60 & High & \multirow{3}{*}{ Ceasefire } \\
\hline & Middle & 55 & Middle & \\
\hline & Low & 50 & Low & \\
\hline \multirow{3}{*}{ Polarization } & High & 45 & High & \multirow{3}{*}{ Accord } \\
\hline & Middle & 40 & Middle & \\
\hline & Low & 35 & Low & \\
\hline \multirow{3}{*}{ Contradiction } & High & 30 & High & \multirow{3}{*}{ Normalization } \\
\hline & Middle & 25 & Middle & \\
\hline & Low & 20 & Low & \\
\hline \multirow{3}{*}{ Difference } & High & 15 & High & \multirow{3}{*}{ Reconciliation } \\
\hline & Middle & 10 & Middle & \\
\hline & Low & 5 & Low & \\
\hline
\end{tabular}

Elaborated by the autor.

4 On the contrary, an act of aggression is considered as unilateral violence. 
development of mechanisms to lower the tension.

There is suspiciousness between the parties and sometimes the will to yield is limited to the steps taken by the counterpart. In a successful level of accord, the parts involved search actively for solutions and involve the civil society in the processes. When the level of intensity of the conflict is still high, the players are incapable to engage with what is necessary to pacify the situation and solve the roots of the conflict, and so they might decide to appeal once again to the use of force.

Normalization: situation tends to stabilize around a point equivalent to "Contradiction". The actors have the will to search for agreements with the object to avoid future strokes. The parts work mainly developing a structure to regulate and facilitate their interactions.

Reconciliation: the conflict is resolved. The parties involved have no particular divergences that could affect their relationship.

The three curves of conflict in Ukraine during the 2013-2014 crisis.

This research covers developments from Nov 21, 2013 to the $23^{\text {rd }}$ of May, 2014. During the study 293 conflict events were identified, evaluated and translated to quantitative data. In this narrated analysis of the results, events are organized in three phases and according to their link to each of the conflicts identified: internal conflict, Ukraine-Russia and West-Russia. These stages are presented corresponding to an interpretative account of the events, according to the cycles observed.

The crisis begins when former President of Ukraine, Viktor Fedorovych Yanukovych, discards signing an accord with the EU to deepen trade. This event indicates the existence of significant polarization within the country towards ideological and economic frameworks available in Europe, once a series of popular manifestations arise against the political decision. Upon these actions, other two conflicts arise at the end of February, between Ukraine and Russia, and Russia and the West. The three of them show their interdependency until the internal conflict in Ukraine derives into a situation of low-intensity war by May, 2014.

\section{Phase 1 - Internal crisis (21 Nov- 23 Feb).}

As a consequence of President Yanukovich's resolution to back away from an agreement to further commerce with the EU, there began a series of popular manifestations in the main cities of the country opposing this political decision. Soon enough polarization translated into violence in the streets. The 21 of November marks 
the starting point of a crisis in motion that expands throughout Ukraine.

Low intensity violence begins by the 25 of November. Verysoon, themassmedia compares the events with the Orange revolution. On the 26 of November the EU rejects Ukraine's proposal to begin talks simultaneously with Russia, a consistent indicator of the existence of an underlying conflict between the West and Russia. By the end of the month, more than 100.000 people gather at Kiev's main plaza rejecting President Yanukovich's decision. Since the $1^{\text {st }}$ of December protesters ask for the President's resignation. Police responds hardly and violence on the streets call the attention of the international community. Incidents of particular violence take place on the 30th of November (2013), 19 and 26 of January and 18, 19 and 20 of February, these dates mark the highest points in the curve during this phase of the crisis. It is relevant to recall that during the incidents in February, 39 police officers are accused of shooting unarmed protesters, infuriating the citizens against the government. However, later reports indicate police officers were also targets. Ex-Ukrainian Interior Minister, Vitaly Zakharchenko, declared to RT ("100\% sure," 2014) that during these days, 86 officers were shot at, 14 of them died, and none of the officers deployed were carrying their service weapons. From another perspective it is relevant to note that the violence and the Ukrainian winter frost was unable to dissolve the will of the protesters on the streets, in this sense calls the attention the fact that they stood up for so many days in the cold. This fact indicate that the issues at stake were of high value, this is the political and economic changes related to the new terms of association with the EU.

The lowest point of intensity during this phase came on 14 February with the liberation of 234 protesters under arrest since December, protesters respond returning public buildings back to authorities. 23 of February marks another low intensity point, when parliamentarians agree to name Olexander Turchynov as interim President of the country, one day after President Yanukovich had been removed from office by the Ukrainian Parliament. The agreement reached on 21 of February has merely a symbolic value, signed one day before Yanukovich's ousting. However, it is relevant to highlight its fourth paragraph: "Investigation into recent acts of violence will be conducted under joint monitoring from the authorities, the opposition and the Council of Europe" (Agreement on the Settlement of Crisis in Ukraine. 21 February 2014). However, a public report consigned that, "Violations by police, including torture and other illtreatment as well as abusive use of force during demonstrations, continued with near-total impunity for the perpetrators, while investigations into such incidents remained ineffective" (Amnesty International, 2015). 
Phase 2 - External conflicts arise, the curve diverges in three

(25 Feb-3 Apr).

In the second phase of the crisis the external conflicts arise with divergent intensities, reason enough to analyze the crisis in Ukraine with a disaggregating perspective, focusing separately into each of the conflicts involved. The crisis of political visions in Ukraine activates other two underlying conflicts, between Kiev and Moscow, and the West and Russia.

\section{Internal}

The 22 of February, when President Yanukovich is removed from office, people in the cities of Bila Tserkva, Khmelnitsky and Zhytomyr bring down statues of Lenin. The next day proRussians stand to protect the statue of the Russian communist revolutionary in Kharkiv. Even after the replacement of the former president there is still unrest, particularly in the Russian-speaking regions of the country where there is opposition to the new administration in Kiev. On the $25^{\text {th }}$ of February, BBC News ("Ukraine crisis," 2014) reports that interim President Turchynov warns of the dangers of separatism. The situation worsens through the first days of March, by the $9^{\text {th }}$, activists have taken the streets of the main cities along the country where clashes have taken place between pro-Russians and pro-Ukrainians. Two days later, Kiev have asked the OSCE to bring observers to the South and East of the country. The government calls for alternative ways to solve the crisis while asking the population not to support unconstitutional activities. Among these events of heightened polarization and low levels of violence of the internal conflict in Ukraine, a different kind of situation begins to unfold in Crimea initiating a second curve.

The second curve with Russia and Ukraine.

On the 26 of February clashes between pro-Russians and anti-Russians, take place on the streets of Simferopol. Up to this point the events in Crimea might be taken as part of the situation of instability taking place in the country as a whole. The next day a pro-Russian command expels the local government of Crimea and takes control of the capital's parliament where they vote to approve a referendum to ask for more autonomy for the region. Men on black uniforms with no flags or banners occupy other key buildings. These unidentified actors impulse the second phase of the crisis with the manifestation of another conflict, the one between Russia and Ukraine, which involves different interests. At this point it is very important to make clear that Russia denied its involvement in the process that derived to the annexation of Crimea, in fact the first comments on the issue by the President of the Russian Federation, Vladimir Putin, were on the $4^{\text {th }}$ of March, denying the presence of Russian troops in the peninsula. But 
one month later he stated on a live TV program that Russian units had been involved in wresting Crimea from Kiev's control, explaining that they had to take unavoidable steps, "so that events did not develop as they are currently developing in southeast Ukraine" (as cited in Anischchuk, 2014). He stated that the annexation was partly triggered by NATO expansion, explaining that:

If Nato goes there, Russia will be pushed out from the area around the Black Sea. This is pushing out Russia from this important part of the world. Let's not be afraid of anything, but we should take that into account, and respond accordingly. (as cited in Gentleman, 2014)

On this phase, the intensity of the crisis oscillates between high levels of violence, to low levels of polarization. On the 28 of February armed men take the airports of Belbek and Simferopol; only then, Kiev accuses Moscow of exerting an armed invasion and occupation. The next day, the Federation Council, approves a military intervention in Ukraine, invoking the right to protect its interests and the Russian speaking population. This event activates the state of alert of the military forces in Ukraine and stands as a warning sign to the West (see below A Third Curve arises following Russia and the West). Reiteratively the government of Ukraine accuses Russian intervention, even Prime Minister Yatsenyuk stipulates that Moscow has declared war ( $2^{\text {nd }}$ of March). Military readiness and high levels of political accusations situates the intensity of the crisis at different levels of violence. As Western powers begin talks with Russia to lower the temperature of the crisis, Ukraine accelerates the pace of its diplomacy to gain support for its cause. On the 6 of March, the Crimean Parliament decides the annexation of the peninsula to Russia and calls for a referendum for the citizens to vote. This same day, Russia sinks one of its own ships in a strategic area of the Black Sea to block the exit of Ukrainian vessels from the Crimean peninsula. The next day, the Russian government declares it will back up Crimea if the region votes favoring the secession of Ukraine. Meanwhile, by the $9^{\text {th }}$ of March, there are clashes between proRussian and anti-Russian factions in the streets of the main cities in Ukraine and the country's Prime Minister, Arseniy Yatsenyuk asks the people not to cede a single centimeter to Russia. Between the 7 and 17 of March, the intensity of the crisis keeps a level of polarization. Nevertheless, the referendum that takes place in Crimea on the $16^{\text {th }}$ would change things forever.

Official data informed that more than $82 \%$ of the population of Crimea participated on the referendum, from which more than 96\% voted in favor to the annexation to Russia. This will becomes a fact on the $18^{\text {th }}$ of March when President Putin signs the documents changing the flag of the Crimean peninsula, situating the curve 
at a high level of violence. This is the latest peak of the curve analyzed during the period under scrutiny, since then, the intensity of the conflict between Russia and Ukraine oscillates between a low level of violence and mid-level of polarization, as it will be described later.

Ukraine's immediate response to the loss of territory is leaving the Commonwealth of Independent States (under the lead of Moscow) on the $19^{\text {th }}$ of March. Two days later, the government signs the political chapters of an agreement of association with the EU and participates in military exercises with NATO in Bulgaria (for two weeks, until the $4^{\text {th }}$ of April). On the $30^{\text {th }}$, Minister of Foreign Affairs of the Russian Federation, Sergey Lavrov, suggests that the federalization of Ukraine is the only way to settle down its political crisis. The $3^{\text {rd }}$ of April, military exercises take place in the Russian region of Volgograd, close to the border with Ukraine. A few days later, when the internal conflict of Ukraine revamps with separatist movements taking control of public buildings in Donetsk and Luhansk on the $6^{\text {th }}$ of April, some sources speak of a 'second wave' of a special operation held by the Russian Federation against Ukraine. These events give way to the third phase of the crisis.

\section{A third curve arises following Russia and the West.}

There is still more to elaborate on the second phase, particularly on the relationship between Russia and the West. On the first day of March, President Obama asks President Putin to withdraw Russian forces back to their military bases; this indicates the beginning of the second part of the second phase of the crisis: when a third conflict unfolds. This one is a reaction to the successes of Russia imposing its interests over the conflict between Moscow and Kiev. It takes the form of a defense of Ukraine's sovereignty and territorial integrity alleging the illegality of the referendum to vote for the secession of Crimea and later the annexation of the peninsula by Moscow, but it is the interest to put a stop to Russian influence in Eastern Europe. Other actors get involved as well, such as NATO, Canada, Poland, OSCE, UN, EU, Switzerland and France. This crisis maintains a relatively low intensity in a state of polarization, until the first days of April, when it reaches a low level of violence, particularly because of accusations and preparations that indicate military readiness.

On the $3^{\text {rd }}$ of March, the Pentagon announces that the US suspends every military ties between Washington and Moscow as a consequence of the Russian intervention in Crimea. Two days later, NATO suspends the participation of Russia in what was going to become their first joint mission; suspends every meeting between military and civilian officers from Russia; and submits to review every aspect of cooperation between 
NATO and Russia. Only political dialogue is open to Ambassador level officers. The following day, Canada expels 9 Russian military officers from the country who were invited as part of a professional exchange program, also suspends every bilateral link with its armed forces including already planned meetings and military exercises. This same day a European Emergency Council condemns the violation of Ukraine's sovereignty and its territorial integrity. By the $8^{\text {th }}$, OSCE monitors receive warning shots for their attempt to visit the Crimean peninsula. On the $11^{\text {th }}$, Didier Burkhalter, leader of the OSCE and Switzerland's Minister of Foreign Affairs, declares that the referendum in Crimea is illegal. On the $15^{\text {th }}$, Moscow vetoes a UN resolution draft that criticized the referendum about Crimea's secession. The next day, voters approve the annexation to Russia, while the EU declares it will not recognize the results because it considered it illegal and illegitimate. The following day NATO states that the referendum is illegal and illegitimate as well. On the $17^{\text {th }}$, the US imposes economic restrictions to a Russian bank and 11 Russian citizens close to President Putin (who allegedly had participated in Crimea's annexation). The next day, NATO condemns Russia's actions incorporating Crimea, while NATO and the US highlight the importance to develop a joint international response to the continuous violation of Ukraine's sovereignty and territorial integrity. Two days later, the EU would also condemn
Russia for Crimea's annexation, and the following day sanctions Russian and Ukrainian citizens that participated in the process.

On the 21 st, NATO's Secretary General, Anders Fogh Rasmussen, considers the crisis in Ukraine as a geopolitical game changer, for which he settles three priorities for the allies to face Russia's military aggression against Ukraine. 1. To reaffirm Allied commitment to collective defense. 2. Strengthen support to Ukraine and the wider region. 3. "And to make clear that we can no longer do business as usual with Russia" (Rasmussen, 2014).

On the 24th , Russia sanctions 13 Canadian government officials as a reprisal for similar measures implemented by that country. On the $27^{\text {th }}$, UN's General Assembly approves a resolution stating that Crimea's referendum is illegal. The following day press reports indicate an increase of NATO military planes in Baltic States. The next day, NATO's commander anticipates his return to Europe from the US after non-confirmed versions of movement of Russian troops along the border with Ukraine. During the first day of April, after indicating no signs of a Russian troop retreat, NATO announces the suspension of every type of military and civilian cooperation with Russia, and asks Generals and Admirals of the Alliance to propose ideas for the defense of members in Eastern Europe. The following day, Jane's publishes satellite photos, which 
indicate an increase of Russian troops in Belgorod (located $40 \mathrm{~km}$ from Ukrainian border), authorized sources estimate the presence of 40 thousand troops. The next day, Russia begins military exercises in the Volgograd area (385 km from Luhansk, Ukraine).

After NATO suspended relations with Russia on April 1st, Russia calls its Ambassador to the entity, indicating it has deliberately heightened the tension. The $4^{\text {th }}$ day of the month NATO's deputy Secretary General, Ambassador Alexander Vershbow, declares that Europe's strategic environment has changed: "for 20 years, the security of the Euro-Atlantic region has been based on the premise that we do not face an adversary to our East. This premise is now in doubt" (Vershbow, 2014).

\section{Phase 3 - Separatism spreads on Eastern Ukraine (6 Apr - 23 May).}

While the Crimean issue is handled by Russia as a fait accompli, the internal conflict in Ukraine revamps with the spread of separatism, particularly in the Eastern regions of the country. As it was anticipated in this text, the separatist movement that take part in Ukraine starting on the $6^{\text {th }}$ of April is perceived as a 'second wave' of Russian activity against Kiev. While Ukraine and the West accuse Russia's involvement in the confrontation, Moscow denies its participation and indicates that the crisis in Ukraine "is to be blamed on those who organized the state coup in Kiev" (as cited in "Kiev says," 2014). Although Moscow has denied its involvement with the separatists movements that emerge after the Crimean issue, it's eventual or possible participation in the conflict is still a debated issue, but there is not enough evidence to directly or strongly accuse Moscow. From a realist perspective, Eastern Ukraine is an area of Russian geopolitical interest, where it has significant influence. The West and Ukraine understand that Russia has to be part of a solution. Therefore, accusations against Moscow gradually mutate to an active interest to involve the Kremlin in the search for solutions to the conflict. It has been necessary to take note of these facts while collecting the data for the research, as a consequence, the events related to the internal conflict have been isolated from the conflict between Ukraine and Russia, as well as from the one between the West and Russia.

Spread of separatism in the internal front.

Until the first days of May, the level of intensity of the internal conflict oscillates between high levels of violence to a mid-level of polarization, taking note that there are many consecutive high points by the end of April.

On the $6^{\text {th }}$ of April separatist groups take control of public buildings of 
cities in Donetsk, Luhansk and Kharkiv. The next day, pro-Russians announce the formation of the Republic of Donetsk, calls for a referendum to be held on the $11^{\text {th }}$ of May, to ask for the annexation to Russia and calls Moscow to send peacekeepers to warrant the feasibility of the process, but none of these occurred. On that same day, the acting President of Ukraine, Oleksandr Turchynov announces prohibition to perform separatist activities in the country. The following day security forces from Kiev begin an antiterrorist operation in Kharkiv. On the $10^{\text {th }}$ of April, the self-proclaimed Republic of Donetsk decides to create a People's Army. There are clashes in the streets of Odessa on the $11^{\text {th }}$ and violence spreads along the Donbass (which includes the regions of Donetsk and Luhansk). On the $12^{\text {th }}$ a security council takes place with the President in Kiev, the next day an antiriot operation takes place in Sloviansk and activists clash in Kharkov. By the $14^{\text {th }}$ there are clashes in 9 cities of the Donetsk region and the city of Sloviansk refuses to transfer taxes to Kiev. That same day, acting President Turchynov signs a decree authorizing a special operation in the East of Ukraine, which begins the $15^{\text {th }}$ in Donetsk with quite an unexpected result: pro-Russian citizens capture about one hundred soldiers and a dozen vehicles.

On the $17^{\text {th }}$ of April the Geneva Accord was signed by representatives from Russia, EU and Ukraine to lower tensions in the East. Despite the agreement, violence continues; separatists did not participate on the arrangements so they do not comply returning public buildings nor with the disarmament. By the $22^{\text {nd }}$ separatists are still active in at least 10 cities and towns occupying public buildings. By the $24^{\text {th }}$ there are more than a dozen. On the $25^{\text {th }}$ rebels take hostage eight European military observers (one is liberated three days later, the rest by the $3^{\text {rd }}$ of May). On the $28^{\text {th }}$ there is an assassination attempt against the mayor of Kharkiv. The next day hundreds of separatists occupy public buildings in Luhansk and take control of the city.

There are at least 40 pro-Russians dead in street clashes in Odessa on the $2^{\text {nd }}$ of May, most of them were burnt alive or suffocated to death in the local House of Trade Unions, "many of those who managed to escape the fire were then brutally beaten by armed men" ("Odessa slaughter," 2014) Struggles continue at least until the $4^{\text {th }}$. On 2 May, a military operation takes

The Council of Europe declared on November 2015 that the official probes into the violent events in Odessa failed to comply with the requirements of the European Human Rights Convention, and reported that there was no substantial progress investigating the events. More in: Council of Europe Blasts Ukraine's Investigations into Odesa Violence (2015, November 4). Radio Free Europe. Radio Liberty. Retrieved from: http://www.rferl.org/content/ukraine-odesa-fire-council-europe-report/27345601.html 
place in Kramatorsk; there are fierce combats against separatists in an effort to recover Slavyansk (in the region of Donetsk). For the first time during the crisis under scrutiny, a conflict reaches the level of war. Fighting continues at least through the $6^{\text {th }}$, according to The Guardian ("Ukraine is close," 2014) this day the German foreign minister declares that Ukraine is a few steps away from a military confrontation.

Afterwards, the situation recedes to a high level of violence. On the $7^{\text {th }}$ the minister of defense of the selfproclaimed Republic of Donetsk is under arrest, this day there is also a prisoner exchange between Ukraine's security forces and Donetsk's auto defense. By the $8^{\text {th }}$ Ukraine confirms it will continue with the military operation in the East. On the $11^{\text {th }}$ referendums about the autonomy of provinces are held in Luhansk and Donetsk, the following day the Popular Republic of Donetsk formally requests the annexation to the Russian Federation. Struggles continue as the EU and Ukraine rejects the referendum, while Russia respects its result. On the $17^{\text {th }}$ the intensity reaches a mid-level of violence when there is a roundtable on national unity in Kharkiv among separatist's occupations. However, this was only a parenthesis, because by the $22^{\text {nd }}$ the conflict increases its intensity again reaching a low level of war, which is maintained the following days. By the $23^{\text {rd }}$, President Putin believes Ukraine had descended into full-scale civil war, but denied that Moscow was behind acts involving pro-Russia separatists (as cited in "Russia's Vladimir," 2014).

Ukraine - Russia.

The conflict between Ukraine and Russia is definitely deescalating in this phase, from a low level of violence to a mid-level of polarization. Amid accusations from Ukraine on the alleged participation of Russia in the Eastern separatist movement, Moscow states that if it is attacked it will have to respond. In this regard, foreign minister Lavrov declares, "We will keep doing everything possible to consecutively protect the interests of Russian diasporas both in Ukraine and in other states" (as cited in Pochuev, 2014). Accordingly, Russia and later Ukraine deploy forces close to the frontier, heightening tensions. From another perspective, while Russia declares its conformity with the Geneva Accords, accuses Kiev of violating it (on $21^{\text {st }}$ of April) and states on the $24^{\text {th }}$ that Ukrainian authorities commit a crime if they use the army against their own people in the East. On the other hand, that same day Ukraine's acting President, Oleksander Turchynov, said in a national address that "Russia is supporting terrorism in our country" (as cited in Vasovic \& Anishchuk, 2014). On the $23^{\text {rd }}$, Russia begins military drills near the border with Ukraine, Russian Federation, Defense Minister, Sergei Shoigu, declared it was on response to "Ukraine's military machine" and NATO exercises in Eastern Europe (as 
cited in Vasovic \& Anishchuk, 2014). By the $30^{\text {th }}$, armed forces in Ukraine are in full military readiness. On the $7^{\text {th }}$ of May, President Putin calls Kiev to stop the security operation held in the East. The next day Ukraine's government declares they have deployed 15.000 troops by the border with Russia. On the $11^{\text {th }}$ Moscow opens a voting station for Ukrainians, the next day an official statement delivered from the Russian president's press service tensions the relationship once again because of an alleged interference in Ukraine's internal matters by supporting the regions' autonomy process:

Moscow respects the expression of will of the population of the Donetsk and Luhansk regions and proceeds on the basis that the implementation of the results of the referendums will be carried out in a civilised way, without any relapse of violence, through dialogue between representatives of Kiev, Donetsk and Luhansk. ("Moscow respects," 2014)

On the $19^{\text {th }}$, the Kremlin criticizes Ukraine's military campaign in the Southeast as well as the process for a constitutional reform because of an alleged lack of transparency. Two days later, Russia initiates the retreat of military forces from Rostov, Belgorod and Bryansk to their permanent bases. On the $23^{\text {rd }}$ Kiev welcomes President Putin's statement that the Kremlin will cooperate with authorities elected in the Ukrainian polls (held on the $25^{\text {th }}$ ).
The West and Russia.

The tension between the West and Russia tends to lower initially along this phase reaching a mid to low level of polarization, from the $8^{\text {th }}$ of April through the $22^{\text {nd }}$. Afterwards, the intensity of the conflict heightens, oscillating from a mid-level of polarization to a low level of violence, until the $19^{\text {th }}$ of May. By the end of the period studied the relationship reaches a low level of polarization with events occurred the $21^{\text {st }}$.

In general terms polarization builds upon the involvement in the situation in Ukraine, while NATO's Secretary General warns Russia not to interfere in Ukraine's internal affairs (8 of April), President Obama asks President Putin to end support to pro-Russian separatists (14 of April) and President Putin urges President Obama to prevent a bloodshed in the country (15 of April). On the 18th both parties reach a mid-level of agreement with the Geneva Accords, but the Kremlin makes very clear it will not accept further sanctions against Russia. On the 21st, US Vice President Joe Biden personally brings to Kiev a new package of nonlethal aid (including medical supplies and helmets). The next day, he declares that Russia should stop supporting "men hiding behind masks" (as cited in Smith, 2014_a). Russian Prime Minister, Dmitry Medvedev, replies stating that Russia is "ready for unfriendly steps" (as cited in Smith, 2014_b). On the 23rd, 
US troops arrive to Eastern Europe initiating a rotatory presence in the region to perform training exercises in Poland, Lithuania, Latvia and Estonia; Dutch fighters intercept two Russian bombardiers in its airspace; and Russian military units initiate drills by the border with Ukraine. As previously noted, the later were triggered as a response to Ukraine's deployment and NATO's exercises in Europe. On the 24th, President Obama, Prime Minister Cameron, Chancellor Merkel, President Hollande, and Prime Minister Renzi decide to impose new sanctions against Russia; the US and EU impose sanctions on the 28th, but these are of such kind that on the 29th the stock market in Moscow responds raising its value. President Putin "responded by threatening to reconsider Western participation in energy deals" in the country (as cited in Tribune wire reports, 2014). On the 29th Canada imposes sanctions as well, and US Secretary of State, John Kerry, declares that "Today, Russia seeks to change the security landscape of eastern and central Europe", adding that whatever path Russia chooses, "the United States and our allies will stand together in our defense of Ukraine" (as cited in Tribune wire reports, 2014).

On the $8^{\text {th }}$ of May, Russia activates a nationwide military exercise simulating a nuclear attack. Leaders of the Collective Security Treaty Organization observed the drills with President Putin, it included the launching of intercontinental missiles from the Northeastern territories and from two nuclear submarines from the Pacific Fleet and the Northern Fleet. On the $19^{\text {th }}$, Moscow calls for a RussiaNATO Council session about the sharp deterioration of the situation in Ukraine (a week later there was still no date for the summit). The $21^{\text {st }}$ Russia initiates the retreat of military forces from Rostov, Belgorod and Bryansk to their permanent bases.

\section{Conclusions}

To measure the intensity of the crisis in Ukraine it was necessary to observe separately each one of the interacting conflicts: the internal one, another between Ukraine and Russia, and the other with Moscow and the West. The timeframe for the study was determined upon the crisis of the internal conflict, 21 of November 2013 through 23 of May 2014, until the appearance of strong signs that the situation was becoming a war. In this regard, 293 conflict events were identified, evaluated and translated to quantitative data. The result of the study is synthesized in the "Curve of Conflict Intensity in Ukraine" shown in Graphic 1.

Phase 1 of the crisis (21 Nov. - 23 Feb.) is almost exclusively an internal issue, except for three events that indicate the existence and interaction of the other two conflicts with this one. The association agreement with the EU and the impossibility of Kiev to negotiate in parallel with Moscow 
forces Ukrainians to a dilemma, they are obliged to choose, so differences emerge. As choosing between one model or the other is a matter of vital interest, a greater part of the population is not apathetic to what is happening on the streets. On the other hand, the government loses legitimacy upon the violence exerted while facing the protests. During this stage, the crisis unfolds mainly at a low level of violence. It is relevant to observe that in this part of the curve, three out of six events that happen at a high level of violence occur in a period of three months. The other situations take place in a period of three days, until institutional instruments allow the Parliament to solve the crisis of legitimacy of the government by assigning an interim President, rapidly lowering down the tension.

The interaction of the three conflicts in Phase 2 (27 Feb. - 6 Apr.) create a confusing meddle of events that are impossible to analyze in one only curve, this is why the author of this study proposes to disaggregate the events to analyze the crisis in three conflicts. Because of this decision, the graphic splits into three different lines that reveal that the three conflicts have different manifestations during the crisis, with differing intensities. It is worthy of note that during the analysis of the events in this phase the method applied reveals its value as a flexible tool that allows the evaluation of a complex situation in a simple way.

The situation involving Russia and
Ukraine has to do with the opposing interests of Moscow to have a sovereign access to the Black Sea and avoid Europe's expansion, and Kiev's will to protect the country's territorial integrity. The conflict manifests at the highest level of violence, particularly during the last days of February, the first days of March and at the middle of this month, consigning the act of aggression performed by Moscow to annex Ukrainian territory. It has to be noted though that the annexation of Crimea happened in less than twenty days avoiding the use of military force and triggering internal drivers that brought legitimacy to the process. Crimea's annexation is also characterized by its speed; Moscow outmaneuvered Kiev, giving no time to oppose a proper response, not even with the help of the international community. The Kremlin acted undercover, giving support to the local population, working with it, in such a way that it seemed like the citizenry had effectively moved the pieces of the chess table. The element of surprise was key to avoid reaching a level of war. Once the Crimean peninsula issue is presented as a fait accompli by the Kremlin, tension tends to lower down, abruptly after the $18^{\text {th }}$ of March to a low level of violence until the first days of April, and gradually downwards to a high and mid-level of polarization during the third phase.

The West-Russia conflict appears as a reaction to Russian maneuvers in Ukraine, as the West intends to broaden its model of influence in 
Eastern Europe, Russia seeks to protect its area of influence. The tension heightens as Moscow succeeds making its interests prevail during Phase 2 . Most events happen at a high level of polarization particularly after President Putin signs the document annexing Crimea, and some even stretch to higher intensity reaching a low level of violence by the first days of April. It might have been too risky for the West to heighten the tension at that point; Russia was responding accordingly to the challenges and had a clear determination of not turning back. This did not mean the West was going to accept Russia's decision so the tension oscillates during the third phase among the different levels of polarization and even low levels of violence.

The internal conflict resumes in Phase 2 as well, in parallel to the events in Crimea, but with an oscillating intensity. There is an interesting continuum during the first days of March at a mid-level of violence, but somehow it defuses after a high peak on the $9^{\text {th }}$. Later the conflict revamps on Phase 3, at a mid-level of violence, a direct consequence of the events that happened earlier in Crimea, as the Russia-Ukraine conflict unfolds with the annexation of the peninsula. On Phase 3, internal secessionist movements find an opportunity to mobilize the population towards achieving independence and the temperature of the conflict rises as separatists challenge the central government. During the last stage of events under scrutiny, the
Geneva agreement generates reserved optimism among the State actors involved but not the separatists, who were not involved in the negotiations. Therefore, the truce extends for less than three days.

Complex situations, such as the crisis in Ukraine challenge models of analysis, but also pushes researchers to pursue flexible applications of theory with the aim to produce better and more accurate findings. The theoretical framework used in this research was originally conceived as a tool to measure a single conflict, but the results in this paper open the door to use multiple curves of intensity to better understand multifaceted struggles. Now there is a clear understanding that in the case of Ukraine there are three interrelated conflicts. Regarding the circumstances on terrain, the most relevant conclusion is that none of the three conflicts is solved, their persistence should only become a warning sign about the situation in Eastern Europe, particularly taking note that the Strategic landscape in the region has critically changed. There is an urgent need to tackle these divergences to avoid further tensions in the future, which might increase the damage of the relations. The academia might be able to produce valuable inputs to help solve differences without strains; it all depends on formulating the proper questions.

Returning to the facts, by the end of November 2015, the threat presented by ISIS has pushed the West and Russia 
to work together, and this venture might work even though there are still latent conflicts that bind them in Eastern Europe.

Graphic 1. Curve of Conflict Intensity in Ukraine (21 Nov., 2013 ict Intensity i

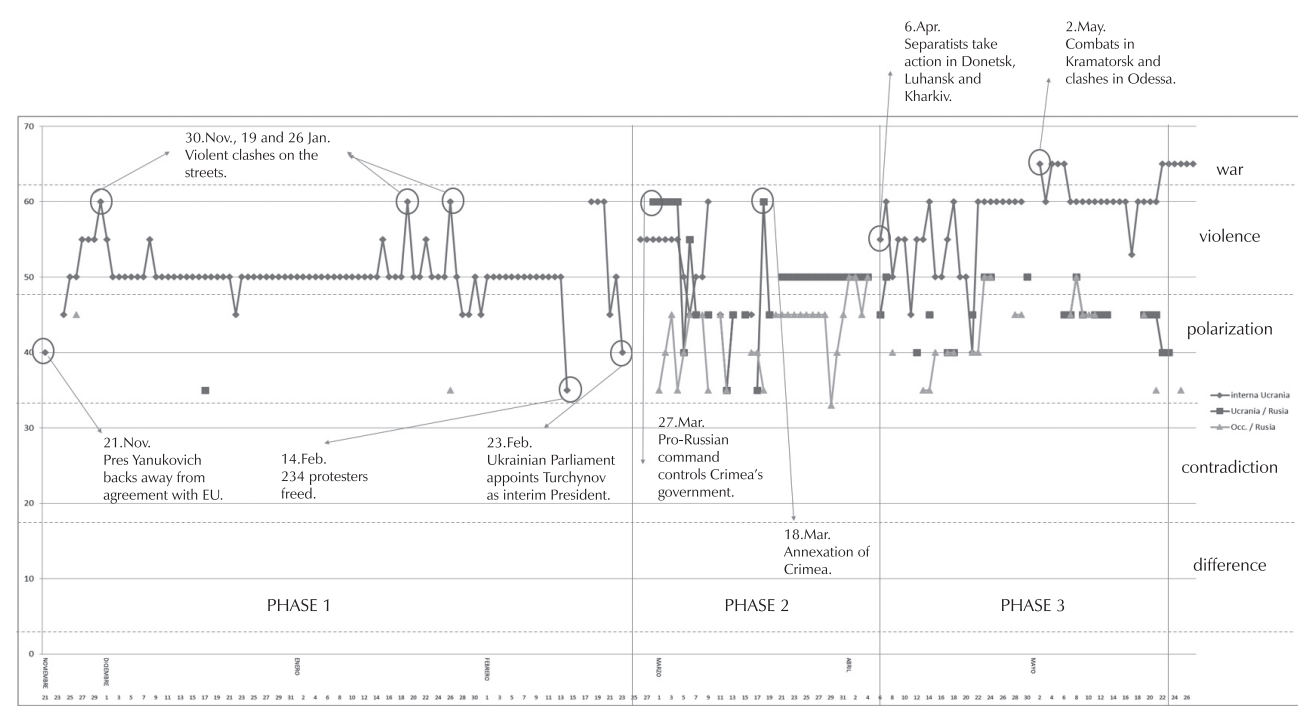

\section{REFERENCES}

Agreement on the Settlement of Crisis in Ukraine. Kyiv, 21 February 2014. Retrieved from: http:// www.auswaertiges-amt.de/cae/ servlet/contentblob/671350/ publicationFile/190027/140221UKR_Erklaerung.pdf

$100 \%$ sure Berkut police didn't shoot people in Kiev' - ex-Ukrainian interior minister. (2014, April 5) RT. Retrieved from: https://www. rt.com/news/snipers-ukrainemaidan-berkut-613/

Amnesty International (2015) The Amnesty International Report 20142015. Ukraine Report. Retrieved from: https://www.amnesty.org/en/ countries/europe-and-central-asia/ ukraine/report-ukraine/

Anischchuk, A. (2014, April 17) Putin admits Russian forces were deployed to Crimea. Reuters. Retrieved from: http://uk.reuters. com/article/2014/04/17/russiaputin-crimea-idUKL6N0N921 H20140417

Dougherty, J \& Pfaltzgraff, R. (1981) Contending Theories of International Relations. A Comprehensive Survey. New York: Harper \& Row, Publishers, Inc.

Gentleman, A. (2014, April 17) Putin asserts right to use force in east Ukraine. The Guardian. Retrieved 
from: http://www.theguardian. com/world/2014/apr/17/vladimirputin-denies-russian-forceseastern-ukraine-kiev

Joint Chiefs of Staff (2010) Department of Defense Dictionary of Military and Associated Terms. (Amended version Oct. 2015). [Ebray version]. Retrieved from: http://www.dtic. mil/doctrine/dod_dictionary/

Kiev says ready for dialogue with Ukraine's federalization supporters. (2014, May 8) Tass. Retrieved from: http://tass.ru/en/world/730860

Lund, M. S. (2009) Conflict Prevention: Theory in Pursuit of Policy and Practice. In J. Bercovitch, V. Kremenyuk, W. Zartman (Eds.), The Sage Handbook Of Conflict Resolution (pp. 287-321). London: SAGE Publications Ltd.

Martínez de Murguía, B. (1999) Mediación y resolución de conflictos. Mexico City: Paidós.

Moscow respects will expressed by population of Donetsk and Luhansk regions of Ukraine. (2014, May 12) Tas. Retrieved from: http://tass.ru/ en/world/731214

Odessa slaughter: How vicious mob burnt anti-govt activists alive. (2014, May 3) RT. Retrieved from: https://www.rt.com/news/156592odessa-activists-burnt-alive/

Pochuev, M. (2014, April 14) Lavrov: Moscow to do its best to protect Russians in Ukraine. Tass. Retrieved from: http://tass.ru/en/russia/727738
Rasmussen, A. F. (2014, March) Address by the NATO Secretary General. Presented at the Brussels Forum conference. Retrieved from: http://www.nato.int/nato_static fl2014/assets/audio/audio_2014 _03/20140321_140321a.mp3

Russia's Vladimir Putin 'to respect' Ukraine vote. (2014, May 23). BBC News. Retrieved from: http:// www.bbc.com/news/worldeurope-27542057

Smith, A. (2014_a, April 22) Biden Slams Russia: Stop Supporting 'Men Hiding Behind Masks'. NBC News. Retrieved from: http://www. nbcnews.com/storyline/ukrainecrisis/biden-slams-russia-stopsupporting-men-hiding-behindmasks-n86416

Smith, A. (2014_b, April 22) Russia Hits Back at Biden: We Are Ready for 'Unfriendly Steps'. NBC News. Retrieved from: http:// www.nbcnews.com/storyline/ ukraine-crisis/russia-hits-backbiden-we-are-ready-unfriendlysteps-n86726

Tribune wire reports (2014, April 30) Ukraine forces in 'full military readiness' un case of Russia invasion. Chicago Tribune. Retrieved from: http://articles.chicagotribune. com/2014-04-30/news/chiukraine-crisis-20140430_1_ ukraine-forces-eastern-ukraineoleksander-turchinov

Ukraine crisis: Turchynov warns of 'separatism' risk. (2014, February 
25). BBC News. Retrieved from: http://www.bbc.com/news/worldeurope-26333587

Ukraine is close to war, warns German minister. (2014, May 6) The Guardian. Retrieved from: http:// www.theguardian.com/world/2014/ may/06/ukraine-claims-30-prorussia-separatists-killed

Vasovic, A. \& Anishchuk, A. (2014, April 25) Ukraine forces kill up to five rebels; Russia starts drill near border. Reuters. Retrieved from: http://www.reuters.com/ article/2014/04/25/us-ukrainecrisis-idUSBREA3L11A20140425

Vershbow, A. (2014, April) A new strategic reality in Europe. Presented at the 21st International Conference on Euro-Atlantic Security, Krakow, Poland. Retrieved from: http://www.nato.int/cps/en/ natolive/opinions_108889.htm

\section{Sources of information used to collect the data to elaborate the curves:}

Aljazeera (http://www.aljazeera.com/)

British Broadcasting Corporation - BBC News (http://www.bbc.com/)

Cable News Network - CNN (http:// edition.cnn.com/)

Chicago Tribune (http://www.chicago tribune.com/)

Deutsche Welle - DW (http://www. dw.com/)
European Union (http://europa.eu/)

Fox News (http://www.foxnews.com/)

International Institute for Strategic Studies - IISS (http://www.iiss.org/)

IHS Jane's (http://www.janes.com/)

Kyiv Post (http://www.kyivpost.com/)

North Atlantic Treaty Organization NATO (http://www.nato.int/)

NBC News (http://www.nbcnews.com/)

Radio y Televisión Española - RTVE (http://www.rtve.es/)

Reuters (http://www.reuters.com/)

RT news (https://www.rt.com/news/)

Stars and Stripes (http://www.stripes. $\mathrm{com} /$ )

Tass Russian News Agency (http://tass. ru/en)

The Guardian (http://www.theguar dian.com/international)

The Independent (http://www.indepen dent.co.uk/)

The Telegraph (http://www.telegraph. co.uk/)

UNIAN Information Agency (http:// www.unian.info/)

United Kingdom Parliament (http:// www.publications.parliament.uk/)

United Press International - UPI (http:// www.upi.com/)

World Affairs Journal (http:// worldaffairsjournal.org/)

World Socialist Web Site (http://www. wsws.org/) 